\title{
ANÁLISE DO VOCABULÁRIO DA CRISE DA REPÚBLICA ROMANA EM 44 A.C. A PARTIR DAS FILÍPICAS, DE CÍCERO
}

\author{
Prof. Dr. Gilson Charles dos Santos ${ }^{1}$
}

\begin{abstract}
Resumo: Da análise feita no presente artigo sobre o vocabulário utilizado por Cícero nas Filípicas para caracterizar Marco Antônio e abordar a crise gerada após o assassinato de Júlio César, deduzem-se os elementos básicos do processo que poderíamos precariamente denominar "transição" da república romana para o principado. Em primeiro lugar, esse vocabulário deflagra a impossibilidade de diálogo entre os adversários - o que incidiria diretamente sobre a justificativa da luta armada -; em segundo, pressupóe o fracasso de condições particulares ao funcionamento das relações sociais dentro da comunidade. Assim, a defesa do tiranicídio e da violência bélica como reação adequada ao comportamento rebelde de Marco Antônio, ainda que pretendesse reparar os danos provocados pelas dissensões entre aristocratas romanos e pelas contendas civis, acabou servindo para a compreensão de como o poder se concentrou nas mãos de um só homem público.

Palavras-chave: Cícero; Filípicas; Júlio César; Guerra Civil; Retórica Antiga
\end{abstract}

Se a definição do modo de atuação política de Júlio César após a Guerra Civil dos anos 49-45 a. C. foi a tirania, a suposição de ela seria derrocada com seu assassinato estava equivocada. $\mathrm{O}$ fato, ao contrário do que se poderia pressupor, escancarou a inconsistência dos propósitos dos assassinos e a falta de coerência da ação da ordem senatorial, além de fomentar uma rivalidade caudilhesca que, com breves intervalos, afundou Roma em quase uma década inteira de novas conflagraçóes civis. Somados, os desdobramentos do assassinato de César configuraram uma grave crise de natureza política e jurídica, deflagrada tanto pelo dissenso acerca das leis e disposições anteriormente elaboradas pelo falecido ditador quanto pelas contrariedades existentes entre o papel por ele assignado a alguns de seus (então considerados) aliados políticos em seu testamento e o crime do qual muitos deles participaram ou foram testemunhas. Um estudo do vocabulário dos elementos dessa crise, ainda que restrito a um escopo de informação preliminar, pode oferecer alternativas de

1 Doutor em Letras Clássicas pela FFLCH-USP; atualmente, é professor adjunto de Língua Latina no Departamento de Linguística, Português e Línguas Clássicas do Instituto de Letras da Universidade de Brasília.E-mail: gcharles@unb.br 
compreensão da postura adotada por aqueles que a venceram e por aqueles que não sobreviveram a ela.

Por vocabulário, entendemos a nomenclatura de qualificação dos elementos da crise de 44 a. C.: o fato que a desencadeou, os sujeitos que a protagonizaram e a sequência de eventos que a concretizou. Ainda que a fonte deste estudo seja única - as Filípicas, de Cícero -, seu autor registra a polifonia de vozes que se pronunciaram quando do assassinato de César, muito embora, reconheça-se, se servisse delas para ratificar sua interpretação do fato; queremos dizer, com isso, que Cícero assinalasse a interpretação da crise de 44 a. C. por parte dos demais envolvidos nela não só como distinta da sua, mas também, em muitos casos, inferior. Em face disso, também nós faremos uma escolha de interpretação. Distantes no tempo, nas circunstâncias e no espaço, utilizaremos, como sugerido no parágrafo anterior, o termo assassinato para o fato, assassinos para os que o perpetraram, envolvidos para os que o testemunharam ou se pronunciaram sobre a crise por ele instaurada e ditador para a vítima do assassinato. Depreende-se, pois, que a expressão vocabulário insinua e explora a existência de uma seleção de termos que acabam por explicitar o dúplice entendimento - que procuramos elencar neste texto - de cada um dos componentes da crise. Tal entendimento depende do ponto de vista adotado pelos envolvidos com relação às ações de Júlio César durante e depois da Guerra Civil de 49- 45 a.C. ou mesmo quanto a ações anteriores à contenda civil, como a conquista das Gálias.

Suposto o uso comum seja iniciar pelo ponto de vista assumido por Cícero nas Filípicas acerca dos elementos da crise, começaremos, porém, por aquilo que o mesmo Cícero reporta acerca de seus adversários. $\mathrm{O}$ principal, mas não o único deles, é Marco Antônio, cuja natureza das ações está subentendida pelo título mesmo da coleção de discursos ${ }^{2}$; afinal, ao se apropriar de maneira jocosa, senão por rivalidade em talento oratório, da designação dos discursos homônimos de Demóstenes contra Filipe II da Macedônia, Cícero reforça a

\footnotetext{
2 Presume-se que Cícero havia pronunciado pelo menos dezessete Filípicas; apenas quatorze chegaram completas aos nossos tempos, bem como fragmentos das demais, que se perderam. A Filípica I foi pronunciada ao senado em 2 de setembro de 44; a Filípica XIV data de 21 de abril de 43. As referências ao título da coleção de discursos como Filípicas constam de uma carta de Marco Bruto a Cícero, datada de $1^{\circ}$, de abril de 43 (Brut. II 3, 4" $\mathrm{Li}$ os dois discursos, um pronunciado no começo de janeiro e outro em que, ao tratar de minha carta, você fez frente a Caleno. O que você espera [ouvir] enquanto os elogio é certamente isto: não sei se nesses discursos a glória é maior pela sua coragem ou pela sua inteligência; estou de acordo que eles sejam chamados de Filípicas, o que chistosamente você escreveu na carta". Legi orationes duas tuas, quarum altera Kal. Ian. usus es, altera de litteris meis, quae habita est abs te contra Calenum. nunc scilicet boc exspectas dum eas laudem. nescio animi an ingeni tui maior in his libellis laus contineatur; iam concedo ut vel Pbilippici vocentur, quod tu quadam epistula iocans scripsisti.).
} 
ideia do medo como mecanismo de dominação, do oportunismo militar como forma injustificada de tomar o poder e do assassinato como um caminho para a libertação. Na Filípica XIII (9, 22- 21, 48), Cícero reproduz e comenta uma carta de Marco Antônio a Otaviano, então pró-pretor, e ao cônsul do ano 43, Aulo Hírcio, a qual reproduzimos abaixo sem os comentários feitos pelo orador durante a leitura aos senadores romanos como ponto de partida para nossa análise:

22. “(...) De Antônio, para Hírcio e César. (...) A notícia da morte de Caio Trebônio não me deixou mais contente, que triste. (...) Que um criminoso fosse punido pelo cadáver e pelas cinzas de um cidadão dos mais considerados e que em menos de um ano se manifestasse a vontade divina (quer fosse mais cedo, quer fosse mais tarde a punição do parricídio) é motivo de alegria (...). 23. (...) Dolabela foi declarado inimigo do povo romano pelo senado por matar um delinquente; é de se lamentar o fato de que o filho de um saltimbanco é mais caro ao povo romano do que César, o pai da pátria (...) 24. O pior de tudo é você, Hírcio, ter sido contemplado com os benefícios de César e ocupar uma tal posição hoje, que faz até você mesmo surpreender-se. (...) E você, rapaz [i. e., Otaviano], 25. que deve tudo ao seu nome, (...) empenhar-se em ser Dolabela condenado pela justiça (...) e em um envenenador ser liberado do assédio (...) a fim de tornar Cássio e Bruto mais poderosos (...) 26. (...) Decerto vocês acreditam que esta conjuntura seja a mesma de outrora (...). Chamam de senado os quarteis de Pompeu (...) 30. (...) Seu general foi Cícero, um derrotado (...). Proveram de exércitos a Macedônia (...). A África, concederamna a Varo, preso duas vezes (...). Para a Síria enviaram Cássio (...) 31. Permitiram que Casca exercesse o tribunado (...). Negaram aos lupercos os tributos de César (...). Acabaram com as colônias de veteranos fundadas por decreto senatorial (...) 32. Prometeram restituir aos massilienses o que lhes arrebatamos por direito de guerra (...). Repetem que qualquer pompeiano sobrevivente não será afetado pela Lei Hírcia (...). Subornaram Bruto com dinheiro de Apuleio (...) 33. Louvaram terem sido decapitados Petreio e Menedemo, que receberam de César a cidadania e eram seus hóspedes (...). Impediram que Teopompo, desprotegido e [não] expulso por Trebônio, fugisse para Alexandria (...). Veem Sérvio Galba nos quarteis armado do mesmo punhal [com que assassinou Júlio César] (...) Recrutaram meus soldados e os veteranos como se fosse para confrontar quem assassinou César; contudo, ao contrário do que eles imaginavam, voltaram-nos contra seu questor, seu comandante e seus companheiros (...). 34 . (...) Por fim, o que houve que vocês não aprovassem ou realizassem que, se estivesse vivo, faria (...) o próprio Cneu Pompeu (...) ou seu filho, caso tivesse meios para tal? (...) Enfim, declaram que a paz é impossível se eu não liberar Bruto ou lhe obstar provimentos (...). E que? É isso o que querem os veteranos, para os quais problema algum 
havia até este momento? (...) 35. [Veteranos esses] que vocês buscaram para corromper com rapapés e promessas (...). Levam, contudo, ajuda aos militares sitiados. Não me oponho a que estejam a salvo e vão aonde queiram, com a condição de morrer quem o mereça (...). 36 . Escrevem que se fez menção à paz no senado e que cinco consulares foram escolhidos como legados. É difícil imaginar que quem repugnou minhas condições justíssimas - algumas das quais eu pensava em remitir - se proponha a fazer alguma coisa com prudência e bondade. Mal posso crer que quem julgou Dolabela inimigo público por conta de seu delito corretíssimo possa nos perdoar, pois estamos de acordo com Dolabela (...) 38. Por essa razão, reflitam se para nosso partido é mais decoroso e produtivo vingar antes a morte de Trebônio, que a de César, ou mais imparcial batalhar pela causa dos pompeianos - tantas vezes arrasada -, que nos avirmos para os inimigos não caçoarem de nós (...) 40. Para eles, matar qualquer um dos nossos será de grande valia no futuro - espetáculo de que até agora a Fortuna nos poupou para não assistir a dois membros do mesmo corpo lutando entre si tendo Cícero como treinador (o qual até o momento está satisfeito por enganá-los com as mesmas artimanhas com as quais ufanou-se de enganar César). (...) 42. Meu propósito é não aceitar desacatos a mim a aos meus, nem descuidar de um grupo que detestava Pompeu, nem permitirei serem os veteranos deslocados de seus lares, nem serem um por um deles assassinados, nem faltar à promessa que fiz a Dolabela (...).43. Nem desfazer a aliança com Lépido, indivíduo impolutíssimo (...).44. Nem que Planco, participante do meu projeto, seja atraiçoado (...) 45. (...) Se os deuses imortais, como espero, me forem generosos em meus planos, viverei contente. Se, ao contrário, outra coisa o fado me apontar, me alegrarei com a defecção das tropas de vocês. Se os pompeianos, que foram vencidos, se mostram tão insolentes, vocês verão, antes dos demais, como eles se comportarão caso vençam (...). 46. Enfim, o que quero dizer é o seguinte: eu poderia suportar os agravos dos meus se também eles [i. e., os pompeianos] quisessem esquecer o que me fizeram ou se dispusessem a vingar comigo o assassinato de César (...). Não creio que os embaixadores venham (...). 48. Quando vierem, saberei o que pedem"3.

\footnotetext{
3 Phil. XIII 10, 22 [...] “Antonius Hirtio et Caesari”. [...] "Cognita morte C. Treboni non plus gavisus sum quam dolui”. [...] "Dedisse poenas sceleratum cineri atque ossibus clarissimi viri et apparuisse numen deorum intra finem anni vertentis at iam soluto supplicio parricidi aut impendente laetandum est" [...] 23. " $<$ A senatu $>$ iudicatum hostem populi Romani Dolabellam eo quod sicarium occiderit et videri cariorem populo Romano filium scurrae quam C. Caesarem, patriae parentem, ingemiscendum est". [...] 24. "Acerbissimum vero est te, A. Hirti, ornatum [esse] beneficiis Caesaris et talem ab eo relictum qualem ipse miraris" [...] “- et te, o puer, - " [...] 25.“- qui omnia nomini debes -" [...]"-id agere ut iure damnatus sit Dolabella -" [...]"- et ut venefica haec liberetur obsidione -" [...] "ut quam potentissimus sit Cassius atque Brutus" [...] 26. [...] “Nimirum eodem modo haec aspicitis, ut priora; -" [...] “- Castra Pompei senatum appellatis". [...] 30. [...] "Victum Ciceronem ducem habuistis" [...] "Macedoniam munitis exercitibus" [...] "Africam commisistis Varo bis capto". [...] "In Syriam Cassium misistis". [...] 31.“"Cascam tribunatum gerere passi estis" [...] "Vectigalia Iuliana Lupercis ademistis" [...] "Veteranorum colonias deductas lege senatus
} 
O teor dessa carta, datada de março de 43 a. C., demonstra a tensão a que chegaram os envolvidos na conjuntura do assassinato de César - a crise já havia sido desencadeada. A essa altura, Marco Antônio se encontrava na Gália Cisalpina liderando tropas macedônicas contra o governador Décimo Bruto, sitiado desde meados de dezembro do ano anterior, enquanto Otaviano e Aulo Hírcio marchavam rumo ao norte da Itália para combater o inimigo senatorial. A carta tem caráter dissuasivo; mais do que ameaça de ataque, busca a conciliação; dirigida a dois generais, reverbera a indignação de seu remetente contra o senado em geral e contra Cícero em particular. Dois são seus efeitos imediatos: de um lado, tipificar a prática dos oponentes que Marco Antônio encontrara no meio senatorial - a começar por Cícero; de outro, articular uma ação de resistência a tal prática, para a qual a cooptação dos generais das tropas do senado se revelava uma estratégia fundamental.

Tais efeitos confluem no entendimento de Marco Antônio quanto ao assassinato de Caio Trebônio; nos fatídicos idos de março, Trebônio distraiu Marco Antônio para que esse não comparecesse à cúria em companhia de

consulto sustulistis" [...] 32. "Massiliensibus iure belli adempta reddituros vos pollicemini" [...] "Neminem Pompeianum, qui vivat, teneri lege Hirtia dictitatis" [...] "Apuleiana pecunia Brutum subornastis" [...] 33. "Securi percussos Petr<ae>um et Menedenum, civitate donatos et hospites Caesaris, laudastis" [...] "Theopompum nudum [non] expulsum a Trebonio confugere Alexandriam neglexistis" [...] "Ser. Galbam eodem pugione succinctum in castris videtis" [...] "Milites aut meos aut veteranos contraxistis tamquam ad exitium eorum qui Caesarem occiderant: et eosdem nec opinantis ad quaestoris sui aut imperatoris aut commilitonum suorum pericula impulistis". [...] 34. [...] "Denique quid non aut probastis aut fecistis quod faciat, si reviviscat -" [...] “- Cn. Pompeius ipse -" [...]"-aut filius eius, si modo possit?" [...] "Postremo negatis pacem fieri posse, nisi aut emisero Brutum aut frumento iuvero" [...] "Quid? hoc placetne veteranis istis, quibus adhuc omnia integra sunt, - " [... $] 35$."- quos iam vos adsentationibus et venenatis muneribus venistis depravatum" [...] "At militibus inclusis opem fertis. Nibil moror eos salvos esse et ire quo libet, si tantum modo patiuntur perire eum qui meruit" 36. "Concordiae factam esse mentionem scribitis in senatu et legatos esse consularis quinque. Difficile est credere eos qui me praecipitem egerint, aequissimas condiciones ferentem - et tamen ex his aliquid remittere cogitantem - putare aliquid moderate aut bumane esse facturos. Vix etiam veri simile est, qui iudicaverint hostem Dolabellam ob rectissimum facinus, eosdem nobis parcere posse idem sentientibus". [...] 38. "Quam ob rem vos potius animadvertite utrum sit elegantius et partibus utilius Treboni mortem persequi an Caesaris, et utrum sit aequius concurrere nos quo facilius reviviscat Pompeianorum causa totiens iugulata an consentire ne ludibrio simus inimicis -" [...] 40."quibus, utri nostrum ceciderint, lucro futurum est, quod spectaculum adbuc ipsa Fortuna vitavit, ne videret unius corporis duas acies lanista Cicerone dimicantis: qui usque eo felix est, ut isdem ornamentis deceperit vos, quibus deceptum Caesarem gloriatus est" [...] 42. "Mibi quidem constat nec meam contumeliam nec meorum ferre, nec deserere partis quas Pompeius odivit nec veteranos sedibus suis moveri pati nec singulos ad cruciatum trabi nec fallere fidem quam dedi Dolabellae -" [...] 43. "- nec Lepidi societatem violare, piissimi hominis -" [...] 44. “- nec Plancum prodere, participem consiliorum. [...] 45. [...] "Si me rectis sensibus euntem di immortales, ut spero, adiuverint, vivam libenter. Sin autem me aliud fatum manet, praecipio gaudia suppliciorum vestrorum. Namque si victi Pompeiani tam insolentes sunt, victores quales futuri sint vos potius experiemini" [...] 46. "Denique summa iudicii mei spectat buc ut meorum iniurias ferre possim, si aut oblivisci velint ipsi fecisse aut ulcisci parati sint una nobiscum Caesaris mortem" [...] "Legatos venire non credo" [...] 48. "Cum venerint, quae postulant cognoscam". 
Júlio César ${ }^{4}$; tempos antes, havia sondado, sem sucesso, sua participação no assassinato ${ }^{5}$; governador da Ásia designado pelo senado, acabou sequestrado pelo colega de Marco Antônio no consulado de 44, Públio Cornélio Dolabela, por cujas mãos foi torturado e morto barbaramente ${ }^{6}$. Estamos, pois, no âmbito de um crime que envolve um consular e um magistrado escolhidos legalmente pelo senado; na carta, porém, o remetente sugere que o criminoso (Phil. XIII 10, 22 sceleratum) seja Trebônio, não Dolabela; o morto, não o homicida.

O termo "criminoso" (sceleratus), quando utilizado por Marco Antônio, aparece nas Filípicas dirigido os assassinos de César; em relação àqueles que não impediram ou contentaram-se com a ação, sua preferência é usar o termo "cúmplice" (socius). Mesmo Cícero reporta ter sido assim qualificado por Marco Antônio (Phil. II 13,31) e insinua que também Décimo Bruto o fosse (Phil. IV 4, 9). Derivado de scelus, o termo carrega a noção de selvageria ou ferocidade que ultrapassa os limites de um crime comum (crimen); seu sinônimo é sicarius ("delinquente", q. v. Phil. XIII 10,23). Ambos os vocábulos são entendidos aqui como antônimos das expressóes "libertadores do povo romano" (liberatores populi Romani) e "preservadores da república" (conservatores rei publicae), tal como Cícero os elenca na Filípica II 13, 31 ao refutar o discurso que, dias antes, Marco Antônio pronunciara contra ele:

"Assim sendo, observe um pouco e reflita como um homem sóbrio por um momento apenas; eu - que (conforme o admito) sou companheiro [familiaris], ou (conforme o admite V. Exa.) cúmplice [socius] desses indivíduos - não me conformo com meios-termos: reconheço serem esses homens, senão os libertadores do povo romano [liberatores populi Romani] e os preservadores da república [conservatoresque rei publicae], mais que criminosos [sicarios], mais que homicidas [homicidas], mais que parricidas [parricidas] - se mais desumano é matar o pai da pátria, que o próprio pai"

Os termos sceleratus e sicarius, claro está, assumem valor legal, dado o fato de que se aplicam àqueles que Marco Antônio julga criminosos. Suas ações constam da missiva enviada a Hírcio e a Otaviano, servindo de escopo

4 Phil. II 11, 27; 14, 34; XIII 10, 22.

5 Pbil. II 14, 34.

6 Phil. XI 2, 4- 3, 8.

7 Phil. II 13, 31 Attende enim paulisper cogitationemque sobrii hominis punctum temporis suscipe. Ego, qui sum illorum, ut ipse fateor, familiaris, ut a te arguor, socius, nego quicquam esse medium: confiteor eos, nisi liberatores populi Romani conservatoresque rei publicae sint, plus quam sicarios, plus quam homicidas, plus etiam quam parricidas esse, si quidem est atrocius patriae parentem quam suum occidere. 
para desmerecer as decisóes do senado - descrito por Marco Antônio como "quartel de Pompeu" (castra Pompei, Phil. XIII 11, 26). Elas refletem, pois, o que Marco Antônio entenderá como "insolência” por parte dos pompeianos (Phil. XIII 20, 45 pompeiani [...] insolentes) por três motivos correlatos:

a) Derrogam resoluçôes de Júlio César (caso das colônias de veteranos e da recompensa financeira aos lupercos, ambas interditadas por decisão senatorial; da restituição dos direitos de cidadania aos massilienses e da indiferença à morte de aliados cesarinos, como Petreio e Menedemo, ou à sua situação, caso de Teopompo);

b) Restituem poder a antigos adversários de Júlio César na Guerra Civil (caso da atribuição do governo da África a Sexto Quintílio Varo, preso na Itália e na África pelas forças cesarinas) ou lhes concedem indulto (caso de Sérvio Galba, um dos assassinos do ditador, e de Marco Bruto, que ademais do perdão recebeu do senado o governo da Síria);

c) Atestam que a ilegalidade não é descartada como método adotado pelos aliados senatoriais, o que sucede com a cooptação das legióes Quarta e Marcial por Otaviano.

O assassinato de Júlio César, por sua vez, é qualificado por Marco Antônio como "parricídio" (parricidi, Phil. XIII 10, 22; parricidae é o termo que designa os assassinos; cf. Phil. II 13, 31); já o ditador, como "pai da pátria" (patriae parentem, Phil. XIII 10,23), título honorífico que condecora cidadãos que realizaram façanhas em defesa da república; a expressão será superada em importância apenas pelo termo Augustus, qualificativo que Otaviano receberá quase quinze anos depois da conjuntura explorada neste texto. Ao tipificar como "parricídio" a prática de seus oponentes, Marco Antônio reafirma a contradição da postura senatorial e desmerece os argumentos que Cícero the dirigira pessoalmente; afinal, também Cícero havia sido designado "pai da pátria" quando da Conjuração de Catilina pelo mesmo senado que acabava de declarar Dolabela como "inimigo do povo romano" (hostem populi Romani, Phil. XIII 10, 23). Ora, qual o sentido de se conferir tamanha honraria a Cícero e de se desqualificar a ação de Dolabela, se ambos deram cabo de criminosos?

O próprio Cícero recupera o motivo pelo qual Marco Antônio utiliza a expressão "parricídio" para atacar seus adversários políticos. Com efeito, Júlio César havia sido honrado pelo senado com o título de "pai da pátria" após a derrota dos pompeianos, em 45. Dias depois de seu assassinato, ergueu-se no fórum uma coluna de mármore dedicada ao ditador com o mesmo título honorífico, junto à qual prestavam-se homenagens e faziam-se sacrifícios em seu nome; isso sugere a longevidade da honraria e sua aceitação popular. Ao 
utilizar o termo "parricídio", Marco Antônio dá a entender que o assassinato de Júlio César foi um ato de revanche, motivado antes por disputas partidárias do que forçosa e consequentemente por reprovação às práticas de governo que César vinha adotando. Tal entendimento é mencionado com deboche por Cícero em, pelo menos, duas ocasióes. Na primeira (Phil. V 12, 32), o orador lembra à audiência que pelo menos dois dos comandantes das tropas senatoriais - Hírcio e Otaviano - não apenas eram aliados de Júlio César, como um deles, ademais, era seu filho adotivo. Na segunda (Phil. XIII 18, 39; 20,47), Cícero esclarece que o termo "partido" (partes) é de uso eleitoral, não cabendo, pois, à composição do senado. Com isso, o orador busca não apenas desqualificar o oponente, como ainda criar junto à audiência o consenso em relação à matéria sobre a qual disserta - a saber, a urgência da ação senatorial em empreender guerra contra Antônio. Procedendo dessa maneira, o que Cícero pretendeu - sem sucesso, adiantamos - foi evitar dissensóes entre senadores, o que retrasaria uma ação mais consistente por parte do grupo.

Emerge daqui o entendimento por parte de Marco Antônio, devidamente registrado por Cícero, de que o orador usava de seu talento oratório para enganar os senadores. Mais do que política, a animosidade de Marco Antônio contra Cícero também é de natureza pessoal ${ }^{8}$. Ao recorrer à eloquência como forma de ação política, Cícero não apenas agiria como um victum ducem, "general derrotado" (o que condiz com o papel atribuído aos pompeianos pelo remetente da carta; Phil. XIII 15, 30; 18, 38), mas igualmente como um "treinador gladiatório" (lanista) cujo método era empregar "as mesmas artimanhas com as quais ufanou-se de enganar César" (Phil. XIII 19, 41). A insinuação da submissão senatorial a Cícero como algo indigno é patente, mas vai além disso: o que Marco Antônio faz aqui é ressaltar a ideia de insurreição de escravos ao modelo daquela de Espártaco - desta feita nascida, porém, no interior mesmo do estamento senatorial. A estratégia visa a convencer Hírcio e Otaviano de que, no instante em que tomam armas contra Marco Antônio, passam a agir como subordinados de Cícero - ou antes, como gladiadores, com todo o significado negativo que o termo encerra.

Contudo, é possível que a concepção de Marco Antônio sobre os elementos da crise de 44 a. C. fosse compartilhada pelos aliados de Júlio César

8 Phil. XII 8,19“Com efeito, com que atitude poderei ver não digo o inimigo da pátria - designação que torna minha raiva congênere à de V. Exas. -, mas um implacável inimigo particular, tal como o provam suas ásperas declarações públicas contra mim?" (Quo enim aspectu videre potero — omitto hostem patriae, ex quo mibi odium in illum commune vobiscum est - sed quo modo aspiciam mibi uni crudelissimum hostem, ut declarant eius de me acerbissimae contiones?). 
que permaneceram no senado após o assassinato do ditador ${ }^{9}$; é também possível que ela servisse como argumento para as ações que Otaviano empreendeu em momentos decisivos da crise sem autorização (ou mesmo à revelia) do senado, reportadas logo no início das Res Gestae Divi Augusti1 ${ }^{10}$. Cícero, porém, ao considerá-las não apenas enganadas, como ainda merecedoras de escárnio, ignorou - talvez involuntariamente - que o discurso dos vencedores estava sendo construído.

\section{Cícero contra Marco Antônio}

Parte essencial do conteúdo das Filípicas procede de respostas que Cícero deu a argumentos de Marco Antônio em preleções (as Filípicas I e II são resultado de duas delas) ou cartas (comentadas pelo orador nas Filípicas VIII e XIII). Sem embargo, o confronto entre tais adversários deu-se unicamente dentro dos limites do debate senatorial: nenhuma das quatorze Filípicas que temos atualmente foi pronunciada por Cícero na presença de Marco Antônio; a Filípica II, aliás, circulou excepcionalmente por escrito sem sequer ter sido apresentada oralmente. A única ocasião em que poderia ter havido um encontro entre inimigos tão acerbos foi a escolha senatorial de Cícero como um dos cinco membros da segunda missão de paz a Marco Antônio, da qual incontinenti o orador declinou alegando a dureza de uma viagem que, aos sessenta e três anos de idade, não conseguiria empreender ${ }^{11}$. Quer pelo motivo da viagem quer pelas dificuldades do caminho, a ameaça de morte era real e os tempos eram outros.

Por conta desse fator - que afinal redimensiona o limite da disputa entre Marco Antônio e Cícero - os esforços do orador concentram-se, em primeiro

9 Citamos, por exemplo, Lúcio Calpúrnio Pisão Cesonino (Phil. XII 1, 3), Lúcio César (Phil. VIII 1, 1-2), Marco Lépido (Phil. XIII 4, 7-8) e Quinto Fúfio Caleno (Phil. X 1, 1-2, 4), que em várias ocasiões discordaram de Cícero, propugnando o diálogo com Marco Antônio.

10 Aug. Anc. 2 (tradução nossa) "Condenei os assassinos de meu pai [qui parentem meum trucidaverunt] ao exílio, vingando-me de seu crime [facinus] num processo legal e, posteriormente, quando iniciaram uma guerra contra a república, derrotei-os em combate duas vezes" (Qui parentem meum trucidaverunt, eos in exilium expuli iudiciis legitimis ultus eorum facinus, et postea bellum inferentis rei publicae vici bis acie)

11 Pbil. XII 9, 22 “Sendo assim, julgam V. Exas. que não devo pensar em meu perigo? Se aqui - estando eu nesta mesma urbe e em meu domicílio - amiúde sofri diversos ataques quando guardavam-me não apenas a lealdade dos amigos, como ainda os olhares da cidade inteira, que armadilhas imaginam V. Exas. não deverei temer iniciando uma jornada, e ademais tão longa?" (Quod cum ita sit, nibilne mibi de periculo meo cogitandum putatis? Hic cum essem in urbe ac domi, tamen multa saepe temptata sunt, ubi me non solum amicorum fidelitas sed etiam universae civitatis oculi custodiunt: quid censetis, cum iter ingressus ero, longum praesertim, nullasne insidias extimescendas?) 
lugar, em exortar o senado a agir ante o fato de Antônio mobilizar exércitos e declarar guerra aos Brutos; em segundo, em criar uma imagem positiva de si mesmo e acentuadamente negativa de seu adversário, de maneira a corroborar o papel que havia assumido com relação à gerência da república em períodos anteriores à crise ${ }^{12}$. Isso não apenas constituía um procedimento retórico por

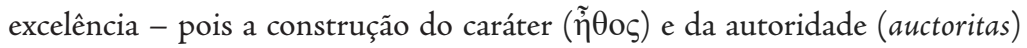
do orador no discurso é elemento essencial para a persuasão -, como ainda respondia a uma necessidade prática: Marco Antônio encontrava defensores dentro do estamento senatorial, os quais não viam necessidade de uma nova conflagração civil para solucionar a crise deflagrada pelo assassinato de Júlio César.

Para levar a cabo esses objetivos, Cícero inverte a nomenclatura dos elementos da crise tal como entendidos por Marco Antônio: chamará o assassinato de Júlio César "uma excelsa e esplendidíssima ação" (Phil. I 4, 9 maximi et pulcherrimi facti) e "déspota" ou "tirano" (Phil. II 34, 85 auctor regni; X 3, 7 nomen regni) o ditador. Qualificará os assassinos como "libertadores da pátria" (Phil. I 2, 6 patriae liberatores; XIV 5, 12 urbis liberatores), "libertadores do povo romano" e"preservadores da república" (Phil. II 13, 31 liberatores populi Romani conservatoresque rei publicae), autodenominando-se "líder da liberdade" (Phil. IV 1, 1 princeps libertatis). O orador, portanto, concebe a ditadura de César como o embrião de um regime despótico, eliminado pelo assassinato de maneira a garantir a preservação da república romana. Insiste, ademais, na pouca variação do qualificativo dos assassinos - mencionados em geral como "libertadores" -, ao mesmo tempo em que amplia a lista de desqualificação dos aliados de Júlio César que permaneceram vivos - e, dentre eles, Marco Antônio especialmente.

Sendo assim, a necessidade da preservação da república romana frente ao despotismo torna "parricidas", "cidadãos pestíferos" (Phil. XI 9, 21 pestiferi cives parricidaeque; Phil. XII 6, 1 importuno et impuro parricidae; Phil. XIII 9, 21 parricida) e "perdidos" (Phil. XII 6, 13 perditi cives) os vingadores de Júlio César ${ }^{13}$, não os assassinos do ditador. Com base nisso, Cícero defende dois princípios para justificar uma guerra: o primeiro, de que os "parricidas" são

12 Phil. II 1, 1“Que sorte é a minha, Pais Conscritos, para não haver ninguém que, nesses últimos vinte anos, afronte a república sem proclamar, ao mesmo tempo, uma guerra contra mim?" (Quonam meo fato, patres conscripti, fieri dicam, ut nemo his annis viginti rei publicae fuerit hostis, qui non bellum eodem tempore mibi quoque indixerit?)

13 A lista é ainda maior; Cícero também os chamará "ímpios" (Phil. XII 7, 15 impii; XIII 1, 2 impiis), "imprudentes" (Phil. XII 7, 15 audaces), "facínoras" (Phil. XII 7, 15 facinerosi), "bandidos" (Phil. XII 7, 15 latronibus; XIII 9, 21 latronum), "insanos" (Phil. XIII 1, 2 consceleratis) e "gladiadores" (Pbil. XIII 9, 21 gladiatorum). 
mais violentos do que os assassinos de César: esses mataram um homem; aqueles pretendem, eliminando concidadãos e tomando suas posses, extinguir a república romana ${ }^{14}$. O crime deles é amplificado. Segundo: ao amplificar o crime da parte contrária, Cícero chama a audiência ao cumprimento de um dever ao mesmo tempo cívico e religioso, que se contrapóe a dois compromissos dos aliados de César - vingar seu assassinato e promover seu culto junto à plebe.

Em mais de uma oportunidade (e por diversos motivos) ${ }^{15}$, Cícero acusa Marco Antônio de desrespeitar os rituais religiosos e lhe atribui uma sanha que torna seu enfrentamento às tropas senatoriais o maior atentado contra a república romana até aquele momento. Com isso, o orador legitima os esforços individuais de Otaviano em conter a ameaça dos militares antonianos; solicita atenção do senado à premência do combate de seu adversário contra os Brutos na Grécia e no norte da Itália e condecora tanto os mortos em batalha quanto quem faleceu em mobilização contra os excessos de Marco Antônio.

A censura de Cícero tanto em relação às práticas de Júlio César quanto às Marco Antônio é justificada não apenas em discursos oratórios, como ainda em tratados filosóficos e mesmo em suas cartas. Ela está alicerçada na ideia de que o despotismo viola os regulamentos que orientam a vida em comunidade e reduz o cidadão romano à condição de escravo. Não por acaso, uma das formas mais recorrentes de apelo ao senado e ao povo romano é a de que urgia a recuperação da liberdade tolhida por Marco Antônio ${ }^{16}$ - ele mesmo, aliás, também escravo da degradação de seus costumes. Mais uma vez, Cícero inverte o papel dos aliados de Júlio César, submetendo-os à condição de gladiadores que almejam a escravização dos demais concidadãos. Procedendo assim, o orador vincula degradação moral, desacordo entre os estamentos da república

14 Phil. VIII 3, 8 "Nós defendemos os templos dos deuses imortais, os muros, os tetos e paredes do povo romano, os altares, as chamas sagradas, as sepulturas dos antepassados, as leis, a justiça, a liberdade, nossas esposas, nossos filhos, a pátria; Marco Antônio, ao contrário, desestrutura tudo isso, luta para eliminar essas coisas todas, subvertê-las, tendo a guerra por pretexto para assaltar a república, dilapidar parte de nossos bens e compartilhar o resto com parricidas" (Nos deorum immortalium templa, nos muros, nos domicilia sedesque populi Romani, aras, focos, sepulchra maiorum, nos leges, iudicia, libertatem, coniuges, liberos, patriam defendimus; contra M. Antonius id molitur, id pugnat, ut haec omnia perturbet, evertat, praedam rei publicae causam belli putet, fortunas nostras partim dissupet, partim dispertiat parricidis).

15 Phil. II 26, 64- 65 e 30, 75 (por adquirir em leilão público os bens de Cneu Pompeu); II 29, 72 (ao participar da Guerra Civil ao lado de Júlio César); XIII 10, 16 (ao enfrentar os exércitos senatoriais); cp. Phil. XIII 7, 16.

$16 \mathrm{O}$ tema da recuperação da liberdade será um dos principais argumentos de Cícero para a guerra contra Marco Antônio; q. v. Phil. III 11, 28; 13, 32; IV 2, 4 et seq.; V 14, 34; 18, 49; VI 6, 19; VII 8, 21; VIII 11, 32; X 7, 15; 8, 16; 9, 19; XI 2, 3; 10, 24; XIII 1, 1; 7, 15; 21, 29; XIV 2, 5. 
romana e mudança da forma de governo. Por conta disso, os argumentos mais frequentes dirigidos contra os aliados de Júlio César nas Filípicas consumam, na prática, uma teoria política que Cícero elaborou durante toda a sua vida madura.

\section{Crise e ocaso da república romana}

É de se notar que a exortação à guerra nas Filípicas tem como fator de oposição a própria cautela senatorial ${ }^{17}$, por cujo expediente Marco Antônio será chamado "adversário" e não "inimigo público" (Phil. XII 7, 17 ego semper illum appelavi hostem, cum alii adversarium) e a crise do ano 44 a. C., incentivada em especial pela formação de tropas por parte de Marco Antônio e de Otaviano, será entendida como "estado de alerta" (Phil. VIII 1, 2 tumultus) e não "guerra" (Phil. XII 7, 17 semper boc bellum, cum alii tumultum). A conjuntura, ao parecer de Cícero, demanda urgência na perseguição aos dois Antônios (Marco e Lúcio) e a Dolabela em vez da busca de diálogo - não raro, Cícero dirá que o que os antonianos chamam "paz" (Phil. XII 1, 2 pacem), o senado deveria chamar "rendição" (Phil. XII 1, 2 deditionis).

O desacordo entre Cícero e parte do estamento senatorial com relação ao protagonismo de Marco Antônio após o assassinato de Júlio César aponta para dois problemas jurídicos. $\mathrm{O}$ primeiro deles deriva da manutenção das leis e indicações (acta Caesaris) do ditador falecido. Com o assassinato de César, Marco Antônio teria a prerrogativa de executar os desígnios de seu colega no consulado, o que só poderia acontecer se César não fosse considerado tirano. Ratificar essa prerrogativa significaria tornar réus os assassinos do ditador. Por outro lado, a anulação dos atos de César, que seria prejudicial tanto para o senado quanto para os veteranos da Guerra Civil, resultaria - claro está na eliminação da prerrogativa de ação de Antônio (ABREU, 2014, p. 7). A anistia geral - ação inédita até aquele momento, que Cícero propôs quando do início da crise - se revelou ineficaz não apenas por indultar os assassinos de Júlio César, como ainda por autenticar todas as decisões de Marco Antônio inclusive retirar setecentos milhões de sestércios do tesouro público, ratificar e abolir leis em nome do ditador morto e recrutar exércitos. Disso deriva que, após o assassinato de César, ao mesmo tempo que os assassinos continuaram

17 Phil. XIV 8, 21 "Contudo, Pais Conscritos, [...] é agora tanto oportuno quanto necessário chamar de inimigo quem o é deveras e em nossos decretos tratá-lo como tal. 22. Quando eu outrora pronunciava os termos inimigo e guerra, com bastante frequência excluíam-se minhas asserções dos pareceres senatoriais - o que nesta causa não se pode fazer" (Sed quod tum non licuit, patres conscripti, id hoc tempore non solum licet verum etiam necesse est, eos qui re sunt hostes verbis notari, sententiis nostris hostis iudicari. 22. Antea cum hostem ac bellum nominassem, semel et saepius sententiam meam de numero sententiarum sustulerunt: quod in bac causa fieri iam non potest). 
sendo uma ameaça latente, o senado ficou, por assim dizer, nas mãos de Marco Antônio.

O segundo problema concerne à mobilização de tropas por parte de Otaviano, que então contava apenas dezenove anos de idade e era filho adotivo do ditador. Para enfrentar Marco Antônio, não haveria pessoa mais indicada - não fosse o fato de que Otaviano não havia desempenhado qualquer magistratura até aquele momento nem poderia naturalmente ser membro do senado; ademais, espelhando-se no pai, poderia também ele buscar o poder tirânico (SCATOLIN, 2015, p. 53). Esse é o pano de fundo do protesto de Marco Antônio pela cooptação de suas tropas por Otaviano (Phil. XIII 17, 35). Cícero, buscando o apoio senatorial às ações do rapaz, utiliza a emancipação como argumento para compensar a contradição formal de se designar "comandante" (imperator) um cidadão que ainda não poderia assumir essa função militar. Com isso, colocou o senado na difícil situação de sancionar uma ilegalidade, ação que exigiu da parte do orador um esforço adicional nem sempre bem sucedido ${ }^{18}$ - de persuasão.

É neste ponto que Cícero correlaciona a controvérsia sobre a questão legal da liderança da guerra contra Marco Antônio por Otaviano à urgência da recuperação da liberdade e das noções de cidadania e participação política. Em primeiro lugar, ao modo de um diagnóstico da situação em que a república romana se encontrava, Cícero lembra a natureza das ações do colega de Júlio César e compara-a com exemplos das guerras civis do passado:

\footnotetext{
"Isso não é uma guerra, ou uma guerra que, de tão terrível, é inédita? Dos demais conflitos - e mormente nos civis -, o foco encontrava-se em desacordos de gerência pública [causa rei publicae]: Sula contendeu com Sulpício pela legalidade das leis que alegava sancionadas por coerção; Cina com Otávio, devido ao sufrágio de novos cidadãos; novamente Sula contra Mário e Carbão, para que sujeitos indignos não nos tiranizassem [dominarentur] e para desafrontar a horrenda matança de cidadãos os mais conspícuos. Nasceram essas discórdias dos desacordos administrativos [ex rei publicae contentione]. Da seguinte conflagração civil não é pertinente a explanação: ignoro seu princípio e abomino seu desfecho"19.
}

18 É de se lembrar que Públio Servílio Isáurico chama os combatentes de Otaviano mortos na Batalha de Mutina de "ímprobos e temerários" (Phil. XIV 3, 7 improbis et audacibus).

19 Pbil. VIII 2, 7 Utrum boc bellum non est, an etiam tantum bellum, quantum numquam fuit? Ceteris enim bellis, maximeque civilibus, contentionem rei publicae causa faciebat. Sulla cum Sulpicio de iure legum, quas per vim [con. Sulla] latas esse dicebat; Cinna cum Octavio de novorum civium suffragiis; rursus cum Mario et Carbone Sulla ne dominarentur indigni et ut clarissimorum hominum crudelissimam puniretur necem. Horum omnium bellorum causae ex rei publicae contentione natae sunt. De proximo bello civili non libet dicere; ignoro causam, detestor exitum. 
“1. Desde o começo desta guerra, Pais Conscritos, que empreendemos contra cidadãos ímpios e criminosos [impiis civibus consceleratisque], temi que a falsa condição de paz extinguisse o empenho na recuperação da liberdade. Paz é um termo doce, e não apenas prazerosa, como também salutar é a sensação mesma. Não parece encarecer os altares domésticos, as leis públicas e o direito à liberdade quem desfruta dos confrontos, do assassinato de cidadãos e da conflagração civil; julgo devesse tal indivíduo ser extirpado do total de homens e privado das marcas da natureza humana. Portanto, quer sejam Sula e Mário, ou ambos; quer sejam Otávio e Cina; quer seja de novo Sula; quer sejam o jovem Mário e Carbão ou outrem que se decida pela guerra civil, avalio-o como um cidadão que já nasceu detestável [detestabilem] para a república. 2. E o que direi do mais recente deles [i. e., Júlio César], cujos Atos - morto com toda a justiça o seu autor - defendemos? Nada foi mais aterrador que esse cidadão, mais terrificante que esse sujeito - se é que foi humano e cidadão -, que buscou a guerra civil. Mas antes é mister atentar, Pais Conscritos, se é possível a paz com todos ou se há alguma guerra inevitável [bellum inexpiabile], posto resultem certas condiçóes de paz [pactio pacis] em termo de escravidão [lex servitutis]. Sula fazia ou encenava a paz com Cipião; não havia motivo de angústia: se chegassem a um acordo, seria suportável a situação da república. Quisesse Cina pôr-se de acordo com Otávio, prevaleceria nesta república as boas relações entre os cidadãos"20.

"Acaso não será, com o maior dos desprezos, salientado nos registros deste estamento que, desde a fundação da cidade, unicamente Marco Antônio cercava-se de homens armados nesta mesma cidade? Assim não procederam nossos reis, nem aqueles que - uma vez desterrados os reis - quiseram poder real [regnum occupare]. Recordo-me de Cina, vi Sula e depois César: esses três, depois de libertada a cidade por Lúcio Bruto, foram mais poderosos do que toda a república"21.

20 Pbil. XIII 1, 2 A principio buius belli, patres conscripti, quod cum impiis civibus consceleratisque suscepimus, timui ne condicio insidiosa pacis libertatis reciperandae studia restingueret. Dulce enim etiam nomen est pacis, res vero ipsa cum iucunda tum salutaris. Nam nec privatos focos nec publicas leges videtur nec libertatis iura cara babere, quem discordiae, quem caedes civium, quem bellum civile delectat, eumque ex numero hominum eiciendum, ex finibus humanae naturae exterminandum puto. Itaque sive Sulla sive Marius sive uterque sive Octavius sive Cinna sive iterum Sulla sive alter Marius et Carbo sive qui alius civile bellum optavit, eum detestabilem civem rei publicae natum iudico. 2. Nam quid ego de proximo dicam, cuius acta defendimus, auctorem ipsum iure caesum fatemur? Nibil igitur boc cive, nibil boc homine taetrius, si aut civis aut homo habendus est, qui civile bellum concupiscit. Sed hoc primum videndum est, patres conscripti, cum omnibusne pax esse possit an sit aliquod bellum inexpiabile, in quo pactio pacis lex sit servitutis. Pacem cum Scipione Sulla sive faciebat sive simulabat, non erat desperandum, si convenisset, fore aliquem tolerabilem statum civitatis. Cinna si concordiam cum Octavio confirmare voluisset, <aliqua> [hominum] in re publica sanitas remanere potuisset. Proximo bello si aliquid de summa gravitate Pompeius, multum de cupiditate Caesar remisisset, et pacem stabilem et aliquam rem publicam nobis habere licuisset.

21 Phil. V 6, 17 An illa non gravissimis ignominiis monumentisque buius ordinis ad posteritatis memoriam sunt notanda, quod unus M. Antonius in hac urbe post conditam urbem palam secum babuerit armatos? Quod neque reges nostri fecerunt neque ei qui regibus exactis regnum occupare voluerunt. Cinnam memini, vidi Sullam, modo Caesarem: bi enim tres post civitatem a L. Bruto liberatam plus potuerunt quam universa res publica. 
"Dois seres somente, desde a origem humana, mostraram-se os mais perversos [taeterrima] e degenerados [spurcissima], Dolabela e Antônio: dos quais um fez o que bem entendeu, e do outro ficou evidente o que pretendia. Foi cruento [crudelis] Lúcio Cina; Caio Mário, de um rancor tenaz [in iracundia perseverans]; Lúcio Sula, devastador [vehemens]. Na vingança, porém, a cólera de nenhum deles foi além da pena capital - e punição alguma considerou-se mais severa contra um cidadão"22.

Desse modo, Cícero divide em dois tipos os conflitos civis de seu tempo: os que, dentro das leis, são resultado do desacordo em matérias de administração e os que, fora das leis, são motivados por interesses pessoais - daí o caso de Júlio César, que iniciou uma conflagração civil após ter sua candidatura in absentia ao consulado recusada pelo senado e, uma vez vencedor, acumulou poder em vez de retirar-se da vida pública, como Sula antes havia feito. Ao segundo de tipo de guerra civil conjugam-se ainda o nível exacerbado de crueldade e o poder desmedido de seus agentes, motivo pelo qual Cícero põe em dúvida inclusive sua caracterização como seres humanos: seu parecer é o de que tais indivíduos recusaram o essencial da natureza humana e as normas da vida em comunidade. Dessa forma estabelecem-se, por oposição às guerras civis, valores que dão sentido à república tal como Cícero a concebe.

Antes de tudo, o termo "república" está sendo entendido aqui como "forma-padrão de convívio humano", não se confundindo com o conjunto de práticas ${ }^{23}$ públicas que denominamos democracia. Tanto o termo grego

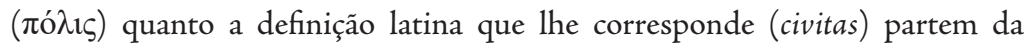

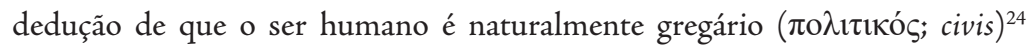
e que as relações entre os seres humanos são reguladas pelas leis com um

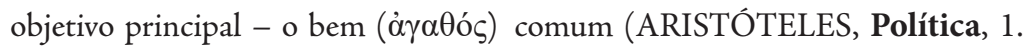
1252a). Já a forma de república adotada pelos romanos até meados do século

22 Phil. XI 1, 1 Magno in dolore, patres conscripti, vel maerore potius, quem ex crudeli et miserabili morte C. Treboni, optimi civis moderatissimique hominis, accepimus, inest tamen aliquid, quod rei publicae profuturum putem. Perspeximus enim, quanta in iis, qui contra patriam scelerata arma ceperunt inesset immanitas. Nam duo haec capita nata sunt post homines natos taeterrima et spurcissima, Dolabella et Antonius: quorum alter effecit, quod optarat; de altero patefactum est, quid cogitaret. L. Cinna crudelis, C. Marius in iracundia perseverans, L. Sulla vehemens; neque ullius horum in ulciscendo acerbitas progressa ultra mortem est, quae tamen poena in civis nimis crudelis putabatur.

23 As práticas referem-se a todas as concepções do que a vida social tem a capacidade de produzir; em termos mais simples, as práticas conjugam o que é, o que pode ser e o que é possível ser no que concerne à vida social (cf. ARAÚJO, 2013, XII).

24 De rep. I 25, 39 "A primeira causa de união não é tanto a fraqueza [humana], mas uma capacidade natural de integração entre os homens" (eius autem prima causa coeundi est non tam inbecillitas quam naturalis quaedam bominum quasi congregatio). 
I a. C., que chamaremos aqui "república romana" (res publica), possui práticas mais específicas, que foram delimitadas por Políbio e Cícero à luz de Platão e Aristóteles.

A definição de república romana por Cícero pressupõe a isonomia legal entre os cidadãos ${ }^{25}$ e o exercício da virtude na vida pública ${ }^{26}$. A isonomia é produto da justiça ${ }^{27}$ e o bem comum, da virtude ${ }^{28}$, porquanto esse esteja firmado na moderação dos interesses individuais a partir da busca pelo consenso entre os membros da comunidade (consensum ordinum). Quanto mais fortes a justiça e a virtude, tanto mais sólida a forma de república (SANTOS, 2007, p. 40). Da mesma maneira, justiça e virtude são essenciais para evitar os excessos que, se no nível individual levam ao sofrimento, no coletivo resultam na mudança da forma de república. Tal formulação é antiga; já Platão (República, VIII, 543a-543c) e Aristóteles (Política, 1, 1252a) definiram os fundamentos da vida em comunidade e Políbio (História, VI, 11-18), fonte de Cícero em seu tratado filosófico Da república, a seu modo aplica-as ao caso romano. A república, habitualmente, é analisada como um corpo, cujas partes possuem, por assim dizer, funções vitais. Nesse pensamento, a virtude e a isonomia fazem pela vida em comunidade o mesmo que os humores fazem pelo corpo humano. Onde há isonomia, há equilíbrio; onde há virtude, não há mudança da forma de república.

Cícero representa o povo romano como um conjunto de cidadãos estruturado politicamente e integrado por meio das leis e dos costumes.

25 De rep. I 32, 49 “Como pode, sendo a lei o vínculo da comunhão civil e o direito conforme à lei, a comunhão dos cidadãos manter-se sem que esses tenham a mesma condição? [...] O que é uma república senão a comunhão legal de concidadãos?" (quare cum lex sit ciuilis societatis uinculum, ius autem legis aequale, quo iure societas ciuium teneri potest, cum par non sit condicio ciuium? [...] Quid est enim ciuitas nisi iuris societas ciuium?).

26 De rep. I 2, 2 "não ter virtude o bastante é como dominar uma técnica sem usá-la” (nec uero habere uirtutem satis est quasi artem aliquam nisi utare); ibid. "mas o seu uso mais necessário é no governo da cidade e nas coisas referentes a isso, que estes homens proclamam em cada canto serem efetuadas de verdade, não anunciadas" (usus autem eius est maximus ciuitatis gubernatio et earum ipsarum rerum, quas isti in angulis personant, reapse, non oratione perfectio).

27 De rep. II 33, 57 "lembrem-se bem do que eu lhes disse no início: se na república não houver equivalência da equidade tanto do direito como do dever e do benefício, de modo que suficientemente corresponda o poder aos magistrados, a autoridade aos líderes das decisões e a liberdade ao povo, não pode a república manter sua composição" (id tenetote quod initio dixi, nisi aequabilis haec in civitate conpensatio sit et iuris et officii et muneris, ut et potestatis satis in magistratibus et auctoritatis in principum consilio et libertatis in populo sit, non posse bunc incommutabilem rei publicae conservari statum).

28 De rep. I 34, 52 “O que pode ser mais ilustre do que a virtude de fato governando a república?” (uirtute nero gubernante rem publicam quid potest esse praeclarius?). 
Concebe, desse modo, um modelo de república que possa, de um lado, ser duradouro e, de outro, que fosse estável, porque apoiado na ideia de colaboração entre cidadãos naturalmente dispostos à associação: a república romana é uma forma alicerçada no equilíbrio e na unidade de suas partes ${ }^{29}$. Em função disso, ela difere de todas as outras formas de república pela originalidade ${ }^{30}$ e por ser regulada por leis criadas por muitos legisladores e durante vários séculos ${ }^{31}$.

Outra distinção da república romana com relação às demais formas de república é o respeito recíproco entre as partes que compóem o corpo civil, derivado da ausência da prerrogativa de cada uma delas executar sozinha uma ação política completa: interdependência cria força (POLÍBIO, História, VI, 18). Um estamento ocupa um espaço adequado e justo em comparação com outro estamento, o que se verifica tanto na formulação e na sanção das leis quanto nas votações ou na atuação militar. Ao mesmo tempo, isso confere importância aos costumes da comunidade e modela o "caráter" da forma de república. No caso romano, o "caráter" da república é a mistura de outras formas (genus mixtum) nas quais a virtude é exercida por todas as partes do corpo civil:

"Esta forma possui, em primeiro lugar, uma grande isonomia - da qual a duras penas os homens livres podem abster-se por muito tempo - e em seguida firmeza, uma vez que aquelas formas primitivas [de repúblicas] facilmente convertem-se em seus vícios contrários, de maneira que do rei surja um tirano, dos aristocratas uma facção, do povo a turba e a confusão. Visto que as formas muitas vezes convertem-se em formas novas, esta forma - oriunda da junção

29 De rep. I 19, 31 [fala de Tuberão], "que tenhamos de fato um só senado e um só povo, e isto é possível, e extremamente danoso se não feito, e sabemos e vemos ser o certo; se concretizado, seremos muito mais vencedores e felizes" (senatum uero et populum ut unum babeamus, et fieri potest, et permolestum est nisi fit, et secus esse scimus et uidemus, si id effectum est, et melius nos esse uicturos et beatius).

30 De rep. II 42, 23 “pois será de uma tal maneira que não se encontrará outra forma de república como essa" (quod erit eius modi, nibil ut tale ulla re publica reperiatur).

31 De rep. II 1, 1“no entanto, nossa república foi constituída não pelo engenho de um só, mas de muitos; não pela vida de um só homem, mas por incontáveis séculos e eras. Nenhum talento disse [Cipião] ter existido como o único a quem nenhuma coisa lhe escapasse, nem que todos os talentos juntos pudessem de uma vez só evitar danos, de maneira que tudo fosse completamente pensado sem a experiência e sem o passar do tempo" (nostra autem res publica non unius esse ingenio, sed multorum, nec una hominis uita, sed aliquot constituta saeculis et aetatibus. Nam neque ullum ingenium tantum existisse dicebat [Cipião] ut, quem res nulla fugeret quisquam aliquando fuisset, neque cuncta ingenia conlata in unum tantum posse uno tempore prouidere, ut omnia complecte rentur sine rerum usu ac uetustate); De rep. II 21, 37 "Então Lélio: "agora esta opinião faz Catão estar mais certo: a constituição de nossa república não se deve a um só homem ou a um só tempo" (Tum Laelius: 'nunc fit illud Catonis certius, nec temporis unius nec hominis esse constitutionem <nostrae> rei publicae). 
equilibradamente misturada [de cada] forma de república - não decai ordinariamente sem os grandes vícios dos governantes. Não há, pois, motivo de transformação quando cada um está firmemente apoiado em seu lugar e não encontre modo de precipitar-se e cair" ${ }^{32}$.

Para que essa forma de república seja estável e, portanto, duradoura, o respeito entre as partes corresponde a certa fraqueza (inbecillitas), uma espécie de "mãe da justiça" ${ }^{33}$, que impede um confronto direto entre os estamentos. A ideia de coesão social deriva, portanto, da ciência da obrigação de cada parte e no respeito dela com relação às demais. Quando não há coesão social, abre-se o caminho para o conflito civil, pensado como uma doença (daí possivelmente a ideia de guerra civil como "guerra intestina", bellum intestinum), e para a desagregação da forma de república. Ao revés, quando há coesão social, o próprio sistema trata de dirimir desacordos.

Em defesa disso, o exercício da virtude na vida pública alça os bons concidadãos à condição de elemento fundamental da existência da república por sua ação moderadora; Cícero os denominará "líderes" (principes). Muito embora o acordo entre as partes - que o orador denomina concordia ordinum - fosse essencial à república romana, de modo que houvesse uma harmonia quase musical entre a ordem elevada, a média e a menor na organização de uma forma de república fundada na isonomia e no bem comum, a organização política também poderia confundir o consenso e a colaboração de todos com a hegemonia de estamentos, tornando assim indispensáveis figuras que atuassem na mediação dos interesses divergentes de cada uma das partes. A república romana é, de acordo com a concepção de Cícero, uma forma em que um elemento supremo e real (os cônsules) governa com a aristocracia (os senadores) e com o povo, numa unidade comparada à soma do corpo com a alma (SANTOS, 2007, p. 44).

O líder (princeps) é um "homem de valor" (cp. Aristot. Pol. 3. 1278b

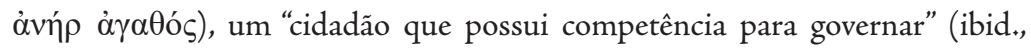

32 De rep. I 45, 69 Haec constitutio primum habet aequabilitatem quandam [magnam], qua carere diutius uix possunt liberi, deinde firmitudinem, quod et illa prima facile in contraria uitia conuertuntur, ut exsistat ex rege dominus, ex optimatibus factio, ex populo turba et confusio, quodque ipsa genera generibus saepe conmutatur nouis, hoc in bac iuncta moderateque permixta constitutione rei publicae non ferme sine magnis principum uitiis euenit. Non est enim causa conuersionis, ubi in suo quisque esta gradu firmiter collocatus et non subest, quo praecipitet ac decidat.

33 De rep. III 13, 23 "mas um temendo outro, um homem temendo outro, uma ordem à outra, e ninguém confiando em si mesmo, forma-se uma espécie de pacto entre o povo e os poderosos" [...] “de fato a mãe da justiça não é a natureza nem a vontade, mas a fraqueza” (sed cum alius alium timet et bomo hominem et ordo ordinem, tum quia sibi nemo confidit, quasi pactio fit inter populum et potentis [...] etenim iustitiae non natura nec uoluntas, sed inbecillitas mater est). 


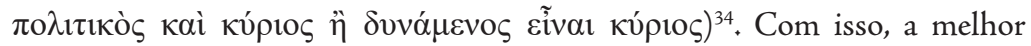
forma de república é aquela que se assemelha ao melhor dos seres humanos ${ }^{35}$; sendo ele virtuoso, também virtuosa será a república ${ }^{36}$. As demais qualidades do líder ciceroniano provêm de postulados da filosofia estoica que, ao modelo de Platão, fundamentem a ação humana no uso da sabedoria (sapientia), de que se entende que um líder é sábio, virtuoso e que, tendo autoridade de julgar e organizar as questóes públicas, identifica-se com um princípio ordenador e soberano (GRIMAL, 1985, p. 246; LEPORE, 1954, p. 82; 88). Por tais características, o líder se opóe à figura do tirano (rex; tyrannus):

\begin{abstract}
"Seja a ele [o tirano] oposto um outro, bom, sábio e destro no serviço e no cargo civil, como tutor e procurador da república. Que assim se denomine quem quer que seja regente e timoneiro da república. Façam por reconhecer esse homem, pois é ele quem pode proteger a república com bom senso e com ações" ${ }^{\prime \prime 2}$.
\end{abstract}

A oposição entre líder e tirano parte da identificação da relação que ambos mantêm com a república: o líder atende às necessidades da vida em comunidade, comungando de seus valores e preservando sua condição livre ao assegurar, como alicerces da melhor forma de república, os costumes, a virtude, a justiça e a equidade; o tirano, por sua vez, torna reféns seus concidadãos em nome do poder individual. É com esse critério que Cícero apresenta o modelo de tirano (Tarquínio, o Soberbo), alertando sobre o perigo representado

34 cp. Cic. Ses. 45, 97 "Mas quantos há entre esses [i. e. os melhores cidadãos]? O total, se mo perguntam, é incalculável (e não há como definirmos): são os líderes do conselho público [principes consili publici], são os que lhes seguem a conduta, são os homens dos estamentos mais altos, aos quais se abre o senado, são os romanos das cidades aliadas e dos campos, são os homens de negócios, estão também entre os optimates [i. e. os melhores cidadãos] os libertos. [...] Os defensores daqueles optimates que respeitam o propósito, as comodidades, as opinióes [dos demais cidadãos] governando a república são eles mesmos optimates, contam-se entre os mais sérios e ilustres cidadãos e os líderes da comunidade [principes civitatis]" (Quis ergo iste optimus quisque? Numero, si quaeris, innumerabiles, neque enim aliter stare possemus: sunt principes consili publici, sunt qui eorum sectam sequuntur, sunt maximorum ordinum homines, quibus patet curia, sunt municipales rusticique Romani, sunt negoti gerentes, sunt etiam libertini optimates. [...] Horum qui voluntati, commodis, opinionibus in gubernanda re publica serviunt, defensores optimatium ipsique optimates gravissimi et clarissimi cives numerantur et principes civitatis).

35 LEPORE, 1954, pp. 87-88, citando Aristóteles, Pol. 2. 1261a 15.

36 De rep. I XXXI, 47 [ed. de Keyes], "Qualquer república é tal qual a natureza ou a vontade daquele que a governa" (talis est quaeque res publica qualis eius natura aut uoluntas qui illam regit).

37 De rep. II XXIX, 51 [ed. de Keyes] sit buic oppositus alter, bonus et sapiens et peritus utilitatis dignitatisque ciuilis, quasi tutor et procurator rei publicae; sic enim appelletur quicumque erit rector et gubernator ciuitatis, quem uirum facite ut agnoscatis; iste est enim qui consilio et opera ciuitatem tueri potest. 
pelo despotismo. É por causa de Tarquínio que, sem grandes distinções, se dá em Roma o nome de "rei" ou "tirano" àquele que exerce qualquer forma de poder personalizado - diferindo do tirano grego que é, essencialmente, um rei injusto $^{38}$ - e que aspira à monarquia. Sob o imperativo da colaboração entre os membros da comunidade, a tirania passa a designar a "não-política", o avesso ou a destruição da política.

Dados esses pressupostos, concebe-se a guerra civil não apenas como expressão inequívoca da ruptura com a comunidade, como ainda, dependendo da motivação de seus protagonistas, uma demonstração de poder tirânico. Não por acaso, Cícero chama a atenção para a diferença entre as contendas civis de Cina, Mário, Sula e César: os três primeiros contenderam, mas não reinaram - ou antes, não romperam com a república; por outro lado, César, após derrotar as forças de Pompeu, não apenas reinou como ainda pretendeu perpetuar-se no poder despótico. A anistia concedida aos assassinos do ditador fundamenta-se na ideia de tiranicídio: morto César, morre também a tirania ${ }^{39}$. Não que os conflitos anteriores já não apontassem uma fratura entre os estamentos da república romana ${ }^{40}$, precipitando o surgimento de déspotas; fato é que, até Júlio César, as contendas civis não haviam, a deduzirse do que Cícero argumenta quando da crise deflagrada pelo assassinato do ditador, demandado um esforço senatorial tão significativo para a recuperação da situação precedente.

Sendo assim, a guerra civil passa a representar a expressão de projetos individuais de poder e o principal motivo de preocupação para o senado, que

38 De rep. I 44, 68; II 27, 49; 30, 52.

39 Pbil. I 1, 3; II 11, 27; 12, 29; 34, 86; 36, 91; 42, 108; X 4, 7.

40 Har. Res. 28, 60 “Possuía outrora a república [civitas] tamanha constância e suficiência, que ao descuido senatorial - e inclusive aos agravos dos cidadãos - poderia desculpar. Já não pode mais. Exauriu-se a fazenda pública, os possuintes não podem desfrutar seus proventos, decresceu a autoridade senatorial, despedaçou-se a concórdia entre senadores e cavaleiros [consensus ordinum], expiraram as sentenças judiciais, poucos indivíduos definem as votações; a disposição dos homens de valor, indolente, desacreditará a requisição de nossa ordem senatorial e, sucedidos todos esses incidentes, debalde requisitarão V. Exas. um concidadão que, em defesa da própria pátria, permaneça inquebrantável. 61. Dessa forma, outro expediente que não a concórdia [concordia] não subsiste com o qual possamos preservar, pouco importa sua natureza, a hodierna composição [statum] da república" (Qua re, id quod extremum est in haruspicum responso, providete ne rei publicae status commutetur; etenim vix haec, si undique fulciamus iam labefacta, vix, inquam, nixa in omnium nostrum umeris cobaerebunt. Fuit quondam ita firma haec civitas et valens ut neglegentiam senatus vel etiam iniurias civium ferre posset. Iam non potest. Aerarium nullum est, vectigalibus non fruuntur qui redemerunt, auctoritas principum cecidit, consensus ordinum est divulsus, iudicia perierunt, suffragia descripta tenentur a paucis, bonorum animus ad nutum nostri ordinis expeditus iam non erit, civem qui se pro patriae salute opponat invidiae frustra posthac requiretis. 61. Qua re bunc statum qui nunc est, qualiscumque est, nulla alia re nisi concordia retinere possumus). 
precede as demais ordens pela autoridade de seus membros e por concentrar o número daqueles que Cícero chama "líderes" (principes; cp. Ses. 45, 97). Ela aponta para o desequilíbrio de funçóes dos estamentos da república romana e para a falta de medidas que restituam o papel dos líderes senatoriais na mediação dos interesses coletivos visando à manutenção do bem comum. $\mathrm{O}$ caso da Guerra Civil entre César e Pompeu tem uma dificuldade adicional - um dos contendentes lutava pelo poder de que não dispunha e o outro, pelo que lhe sobejava ${ }^{41}$. Contra as acusações pessoais de subserviência que Marco Antônio lhe imputara, Cícero admite, na Filípica II, sua parcela de responsabilidade no distanciamento entre Júlio César e Cneu Pompeu quando havia solicitado a esse que fizesse o possível para impedir a candidatura in absentia daquele ao consulado de 49 a. C. e quando, anos antes, lhe pedira (a despeito mesmo da situação de produção e do conteúdo do discurso De provinciis consularibus) que não concedesse a César a prorrogação de seu proconsulado nas Gálias. Soma-se a isso o ter pedido a Pompeu que jamais se associasse a Júlio César no foedus amicitiae (o que de mal grado chamamos hoje "Primeiro Triunvirato") ou que, aliando-se a ele, jamais se desfizesse da parceria, sob a pena de causar a desgraça de toda a comunidade ${ }^{42}$. Tal proposição reforça o fato de que a Guerra Civil, pelo interesse que norteou os atos de ambos os contendentes, concorreu para a deterioração do modelo de república romana que ele, Cícero, defendia

41Phil. XIII 1, 2 "Nessa última guerra, se Pompeu algo abnegasse de sua austeridade, e César muito de sua ganância, poderíamos não apenas ter uma paz inalterável, como ainda um resquício da república" (Proximo bello si aliquid de summa gravitate Pompeius, multum de cupiditate Caesar remisisset, et pacem stabilem et aliquam rem publicam nobis habere licuisset); cp. Luc. I 125-126; Flor. Epit. II 13, 2, 14.

42 Phil. II 9, 24 "Contudo, foram duas as situações em que procurei engendrar em Pompeu alguma antipatia contra César - controverta-as V. Exa., caso possa: a primeira, para que não fosse o mando de César prorrogado em cinco anos; a segunda para que - como ele estivesse ausente - a candidatura não lhe fosse autorizada. Se de qualquer uma delas eu o tivesse persuadido, jamais enfrentaríamos tamanha calamidade. Da mesma maneira - quando já havia Pompeu cedido a César todos os destacamentos seus e do povo romano e, muito mais tarde, começara a perceber o que bastante tempo antes eu lhe advertira -, eu - como enxergasse aproximar-se da cidade uma conflagração desastrosa - não deixei de interceder pela paz, pela concórdia e pelo entendimento, e muitos se recordam de minhas palavras: Quisera, Cneu Pompeu, jamais estabelecesse V. Exa. aliança com Caio César, ou jamais a dissolvesse! Concernia aquilo à compostura de V. Exa.; e isso, à sua prudência. Tais, Marco Antônio, foram minhas apreciações desde sempre tanto de Pompeu quanto da república; fossem elas consideradas, a república permaneceria, e V. Exa. desapareceria sob sua degradação, ignomínia e desprestígio" (Duo tamen tempora inciderunt quibus aliquid contra Caesarem Pompeio suaserim; ea velim reprehendas, si potes: unum ne quinquenni imperium Caesari prorogaret, alterum ne pateretur ferri ut absentis eius ratio baberetur. Quorum si utrumvis persuasissem, in has miserias numquam incidissemus. Atque idem ego, cum iam opes omnis et suas et populi Romani Pompeius ad Caesarem detulisset seroque ea sentire coepisset quae multo ante provideram, inferrique patriae bellum viderem nefarium, pacis, concordiae, compositionis auctor esse non destiti, meaque illa vox est nota multis: "Utinam, Pompei, cum Caesare societatem aut numquam coisses aut numquam diremisses! Fuit alterum gravitatis, alterum prudentiae tuae". Haec mea, M. Antoni, semper et de Pompeio et de re publica consilia fuerunt; quae si valuissent, res publica staret, tu tuis flagitiis, egestate, infamia concidisses). 
como a melhor das formas de república. Ademais, se depois da Guerra Civil a república romana agonizava, isso ocorreu por falta de tato de Pompeu Magno - que, sem avaliar a experiência que Júlio César adquirira em uma década de pacificação dos gauleses, lançou-se numa guerra que pedia um enorme efetivo militar e grandes recursos financeiros.

Considerada a natureza dessa guerra civil, o tiranicídio poderia devolver a república romana à normalidade cumprindo quatro exigências: a reafirmação do bem comum pela eliminação do tirano e da tirania; a ressignificação do ideal de liberdade dos cidadãos, cuja ação política deixaria de ser mediada pelo arbítrio de um indivíduo; a recuperação de antigas práticas da república romana, que incluem a indicação senatorial das magistraturas cumpridas pelo homem público após o consulado e a restauração da sanidade jurídica pela abolição de leis estabelecidas pelo tirano ${ }^{43}$. Contudo, claro está que o assassinato de Júlio César não resultou na efetuação de qualquer uma dessas exigências - muito pela falta de consenso da ordem senatorial, então composta por importantes aliados do ditador.

Em vista disso (e para não cair em contradição ao respaldar a liderança de Otaviano às tropas senatoriais), a estratégia que Cícero novamente emprega contra seus adversários políticos é negar-lhes a cidadania ${ }^{44}$ no intuito de tornar a guerra civil um bellum inexpiabile (Pbil. XIII 1,2) - uma guerra impreterível e, porquanto deflagrada contra não-cidadãos (hostis) ${ }^{45}$, justa. Dessa forma,

43 Ao condenar Bruto pelo assassinato de Júlio César, em seu De Beneficiis II 20, 2, Sêneca apresenta quatro motivos para o assassino julgar que, eliminando César, estava agindo corretamente e pelo bem comum: o primeiro, que livrava Roma do arbítrio de um rei (aut regis nomen extimuerit); o segundo, que a libertas recuperada favoreceria à ação dos cidadãos (aut ibi sperauit libertatem futuram, ubi tam magnum praemium erat et imperandi et seruiendi); o terceiro, que a morte de César significaria o retorno aos antigos costumes republicanos (aut existimauit ciuitatem in priorem formam posse reuocari amissis pristinis moribus futuramque ibi aequalitatem ciuilis) e o último, que as leis enfim valessem frente à ameaça do poder tirânico (et staturas suo loco leges, ubi uiderat tot milia bominum pugnantia, non an seruirent sed utri).

44 Denegar-lhes a cidadania significa privá-los do respeito ou temor religioso, do amor filial e fraternal e dos valores que identificam o homem público como ser humano; cp. Phil. XIV 10, 27 “Com essas vinte coortes - e sem cavalaria -, Hírcio - portando ele mesmo a águia da Quarta Legião (belíssima imagem que não vimos com qualquer outro comandante) - deu combate a três legiôes e à cavalaria de Antônio e prostrou, derrotou e exterminou os inimigos nefastos que ameaçavam este Templo de Júpiter Ótimo Máximo e o dos demais deuses imortais, os tetos desta cidade, a liberdade do povo romano, nosso sangue e nossa existência" (His viginti cohortibus nullo equitatu Hirtius ipse aquilam quartae legionis cum inferret, qua nullius pulchriorem speciem imperatoris accepimus, cum tribus Antoni legionibus equitatuque conflixit bostesque nefarios buic Iovis Optimi Maximi ceterisque deorum immortalium templis, urbis tectis, libertati populi Romani, nostrae vitae sanguinique imminentes prostravit, fudit, occidit). O procedimento já havia sido adotado anteriormente contra Públio Clódio Pulcher, responsável pelo exílio sofrido pelo orador entre 58 e 57 a. C.; cf. Parad. IV 29.

45 Phil. II 1, 2; 21, 51; 25, 89; III 3, 6; 6, 14; IV 1, 1- 2; 2, 5- 6; V 4, 9; 8, 21; 9, 25; 11, 29; VII 2, 5; 3, 9- 10; 4, 11; 13; 5, 15; VIII 2, 6; 10, 29; X 10, 21; XI 1, 3; 2, 6; 4, 9; 5, 12; 6, 15; 7, 16; 12, 
Lúcio Antônio não será tido como cidadão romano, mas sim encarnará um determinado perfil de gladiador, o "mirmilão" (myrmillo $)^{46}$; Lúcio Decídio Saxa e Cafão, membros designados por Marco Antônio para a comissão dos sete responsáveis pela distribuição de terras aos veteranos de César, farão parte de um grupo de comediantes, jogadores, proxenetas e bufóes (Phil. V 3, 7; 7, 2122; VI 5, 14; VIII 9, 26; XI 6, 13; XII 9, 23; XIII 2, 2; 18, 37) $)^{47}$ e Marco

29; 15, 38; XII 3, 8; 7, 17; 8, 19- 20; 10, 24; XIII 3, 5; 6, 14; 9, 21; 10, 23; 15, 32; 18, 39; XIV 1, $1 ; 3,6-7 ; 4,9-10 ; 5,12 ; 8,21-22 ; 9,24 ; 10,27 ; 14,36-38$.

\section{Phil. III 12, 31; V 7, 20; VI 4, 10; 5, 13; VII 6, 17; XII 8, 20.}

47 Cícero nomeia com desprezo e ironia os aliados de Marco Antônio em Phil. XIII 2, 3 "Pode haver paz com os Antônios, com Censorino, com Ventídio, com Trebélio, com Béstia, com Núcula, com Munácio, com Lentão, com Saxa? Menciono esses poucos como exemplo; o número é imenso. V. Exas. mesmos identificam a perversidade dos demais. 3. Somem-se a esses os náufragos amigos de [Júlio] César - os Barbas Cássios, os Barbácios, os Poliões -; somem-se os parceiros e os camaradas de Antônio - Eutrapelo, Mela, Pôncio, Célio, Crassício, Tirão, Mustela, Petúsio. Passo em silêncio a comitiva; chamo atenção para os líderes [duces]. Acrescentem-se os alaudas e os demais veteranos, o seminário de juízes da terceira decúria - os quais, dissipados os seus bens e consumidas as mercês de César, cobiçaram nosso patrimônio" (Cum Antoniis pax potest esse, cum Censorino, Ventidio, Trebellio, Bestia, Nucula, Munatio, Lentone, Saxa? Exempli causa paucos nominavi; genus infinitum inmanitatemque ipsi cernitis reliquorum. 3. Addite illa naufragia Caesaris amicorum, Barbas Cassios, Barbatios, Polliones; addite Antoni conlusores et sodales, Eutrapelum, Melam, Pontium, Coelium, Crassicium, Tironem, Mustelam, Petusium: comitatum relinquo, duces nomino. Huc accedunt Alaudae ceterique veterani, seminarium iudicum decuriae tertiae, qui suis rebus exhaustis, beneficiis Caesaris devoratis fortunas nostras concupiverunt); Phil. XIII 12, 26 "Por acaso chamaremos de senado os acampamentos de V. Exa.? Neles, V. Exa. é obviamente um consular, cujo consulado inteiro não recebeu qualquer registro: dois pretores perderam a esperança, se é que a tinham, de receber abono - posto defendermos os Atos de César -; outros dois pretores: Ânio Filadelfo e o inocente Gálio; os edis: Béstia - treinador de minha voz e de meus pulmões -; o patrono de confiança e fraudador de seus credores, Trebélio; um sujeito falido e arruinado Quinto Célio - e o melhor amigo de Antônio, Vário Cotila - a quem, por puro prazer, Antônio exigia fosse nos banquetes açoitado por escravos públicos; septênviros: Lento, Núcula e Lúcio Antônio - benquisto e amado pelo povo romano; tribunos - em primeiro lugar, os designados -: Túlio Hostílio - que, por decisão própria, escreveu seu nome num portão por onde, como não pudesse atraiçoar seu comandante, desertou; e o outro eleito foi um tal Insteio - ladrão ousado (dizem), que contam ter trabalhado nas termas de Pisauro. 27. Seguem-se os demais tribunos: em primeiro lugar, Tito Planco - o qual, se prezasse o senado, jamais o incendiaria. Condenado por tal atentado, com armas regressou à mesma cidade de onde havia sido escorraçado pelas leis. Isso ele comunga com tantos outros semelhantes seus. O mais admirável é não aplicar-se a Planco o que diz o provérbio: "não pode morrer se não lhe quebram as pernas". Tem as pernas quebradas, e vive. Isso - como outras coisas - dizem ter sido presente de Áquila. Está aí também Décio procedente (presumo eu) dos Mures Décios - que também corroeu os donativos de César. Com efeito, a memória dos Décios, desde há muito esquecida, foi por mérito dele - homem dos mais preclaros - renovada. E como posso preterir Decídio Saxa - sujeito trazido do fim do mundo para vermos como tribuno popular quem jamais víramos como concidadão? 28. Outro que aí está é Saserna; todos, porém, guardam tanta semelhança entre si, que desacerto seus nomes. Não se deve esquecer também Extítio - irmão de Filadelfo, o questor - para não parecer, em caso de preteri-lo, que invejo Antônio. Também está Asínio - senador por decisão própria, eleito por si mesmo. Viu a cúria aberta após o decesso de César; trocou os sapatos e de repente fez-se Pai Conscrito. Desconheço Sexto Albésio; contudo, jamais encontrei alguém tão maledicente que não o julgasse merecedor do senado de Antônio. Creio ter me esquecido de outros; de quem me lembrei não pude deixar de falar. Fiado em tal senado, Antônio ignorou o senado de Pompeu, no qual havia uma dezena de consulares que, de estarem vivos, decerto não haveria esta contenda: a 
Antônio não apenas será comparado ao mais cruel dos adversários romanos (Antônio é denominado "novo Aníbal" em Phil. XIII 11, 25 nove Hannibal; cp. Phil. V 9, 25 Ergo Hannibal hostis, civis Antonius?), como ainda francamente diminuído na comparação com Júlio César ${ }^{48}$. Em comum, todos eles serão

arrogância cederia à autoridade" (An vero tua castra potius senatum appellaremus? In quibus tu es videlicet consularis, cuius totus consulatus est ex omni monimentorum memoria evulsus; duo praetores sine causa diffisi se aliquid habituros - nos enim Caesaris beneficia defendimus -; praetorii Philadelphus Annius et innocens Gallius; aedilicii corycus laterum et vocis meae, Bestia, et fidei patronus, fraudator creditorum, Trebellius, et homo diruptos dirutusque Q. Caelius, columenque amicorum Antoni, Cotyla Varus, quem Antonius deliciarum causa loris in convivio caedi iubebat a $s<e r>v i s$ publicis; septemvirales Lento, Nucula, tum deliciae atque amores populi Romani, L. Antonius; tribuni <plebis $>$ duo designati, primum Tullus Hostilius, qui suo iure in porta nomen inscripsit qua, cum prodere imperatorem suum non potuisset, reliquit; alter est designatus Insteius nescio qui fortis, ut aiunt, latro; quem tamen temperantem fuisse ferunt Pisauri balneatorem. 27. Secuntur alii tribunicii, T. Plancus in primis: qui $<n i>$ si senatum dilexisset, numquam curiam incendisset. Quo scelere damnatus in eam urbem redi<i>t armis, ex qua excesserat legibus. Sed hoc ei commune cum pluribus sui simillimis. Illud tamen <non> verum in hoc Planco quod proverbi loco dici solet, perire eum non posse, nisi ei crura fracta essent. Fracta sunt, et vivit. Hoc tamen, ut alia multa, Aquilae referatur acceptum. Est etiam ibi Decius, ab illis, ut opinor, Muribus Deciis, itaque Caesaris munera erosit: Deciorum quidem multo intervallo per bunc praeclarum virum memoria renovata est. Saxam vero Decidium praeterire qui possum, hominem deductum ex ultimis gentibus, ut eum tribunum plebis videremus, quem civem numquam videramus? 28. Est quidem alter Saserna; sed omnes tamen tantam babent similitudinem inter se, ut in eorum praenominibus errem. Nec vero + Extitius + , Philadelphi frater, quaestor, praetermittendus est, ne, si de clarissimo adulescente silvero, invidisse videar Antonio. Est etiam Asinius quidam senator voluntarius lectus ipse a se. Apertam Curiam vidit post Caesaris mortem: mutavit calceos; pater conscriptus repente factus est. Non novi Sex. Albesium, sed tamen neminem tam maledicum offendi qui illum negaret dignum Antoni senatu. Arbitror me aliquos praeterisse; de iis tamen, qui occurrebant, tacere non potui. Hoc igitur fretus senatu Pompeianum senatum despicit, in quo decem fuimus consulares: qui si omnes viverent, bellum omnino hoc non fuisset; auctoritati cessisset audacia).

48 Phil. II 45, 116 "Além do mais, em caso de V. Exa. não temer os homens de coragem e os cidadãos eminentes - porquanto de sua pessoa afugenta-os com armas - também não poderão os seguranças de V. Exa. - acredite-me - suportá-lo por muito tempo. Que vida, pois, é esta - temer dia e noite seus semelhantes? A não ser, certamente, que os subordine V. Exa. com obséquios maiores que aqueles com que César conformou alguns de seus homicidas, ou possua V. Exa. algo em que comparar-se com ele. Houve em [Júlio] César perspicácia, discernimento, imaginação, talento para as Letras, ponderação, cautela, determinação. Realizou façanhas em batalha - e, conquanto catastróficas para a república, ainda assim excepcionais -; durante muitos anos preparou-se para reinar - e, à custa de um grande esforço e enormes ameaças, conseguiu o que meditara; com espetáculos, monumentos, gratificações e banquetes abrandou a multidão imperita; aos seus sobressaiu-se com recompensas e aos adversários, com uma clemência dissimulada. Que mais? Trouxe a uma cidade então livre a prática de - parte por medo, parte por inércia submeter-se. 117. Posso com ele comparar V. Exa. na ambição de reinar; no demais, decerto não há semelhanças. Mas, fora os inúmeros males que César entalhou na república, resta o bem de haver o povo romano aprendido o quanto confiar em cada um, a quem se entregar, de quem suspeitar. V. Exa. não pensa nisso? Não compreende bastar aos homens de coragem o ter aprendido quão belo em si mesmo, quão prazeroso pelo proveito, quão notável pelo renome é assassinar um tirano? Acaso aqueles que não suportaram César tolerarão V. Exa.? 118. Com obstinação - acredite-me haverá quem se apresse doravante a tal resultado, sem deixar passar a ocasião" (Quodsi non metuis viros fortis egregiosque civis, quod a corpore tuo probibentur armis, tui te, mibi crede, diutius non ferent. Quae est autem vita dies et noctes timere a suis? Nisi vero aut maioribus babes beneficiis obligatos quam ille quosdam babuit ex iis a quibus est interfectus, aut tu es ulla re cum eo comparandus. Fuit in illo ingenium, ratio, memoria, litterae, cura, cogitatio, diligentia; res bello gesserat, quamvis rei publicae calamitosas, at tamen magnas; multos annos regnare meditatus, magno labore, magnis periculis, quod cogitarat effecerat; muneribus, monumentis, congiariis, epulis multitudinem imperitam delenierat; suos 
"inimigos da paz, da concórdia, das leis, do direito e da liberdade" (Phil. XI 14, 36 oti, concordiae, legum, iudiciorum, libertatis inimicos), o que ressalta, por antítese, todo o exposto acima sobre as condições da vida em comunidade.

$\mathrm{O}$ aviso de Cícero ao senado é equivalente àquele que Marco Antônio faz a Otaviano e a Aulo Hírcio na missiva com que abrimos nossa discussão; ele inverte, porém, o antagonista: submetido a Marco Antônio, o senado denegará seu dever de servir aos interesses da comunidade, rebaixando-se à escravidão. Nisso, comete a dupla injustiça de não reconhecer os que se submeteram aos imperativos da república ${ }^{49}$ e legitimar, de maneira obscena, posturas que comprometam a sua própria existência:

“Disso Marco Lépido também deve prover-se, para não parecer agir com presunção maior do que aquilo que seus costumes expressam. 14. Se nos intimida com um exército, esqueceu-se que tal exército é do senado, do povo romano e da república inteira, não seu. "Mas poderia usá-lo como seu". Farão tudo o que podem fazer os homens de valor, mesmo se torpe, pernicioso ou completamente ilícito? O que há, pois, mais torpe, mais marginal ou mais obsceno do que liderar um exército contra o senado, contra os concidadãos, contra a pátria? O que merece detração maior do que agir ilegalmente? Ninguém pode guiar um exército contra a pátria, se o que chamamos lícito é outorgado pelas leis, pelos costumes e instituições de nossos ancestrais. Nem tudo o que alguém possa fazer é lícito ou, apenas por não lhe ser denegado, permitido. A V. Exa., Lépido, como a seus ancestrais a pátria concedeu tropas: para defendê-la. Com elas, V. Exa. debelará o inimigo, dilatando as fronteiras de nosso poderio; obedecerá ao senado e ao povo romano, se porventura o destinarem a outra ocupação" 50 .

praemiis, adversarios clementiae specie devinxerat. Quid multa? Attulerat iam liberae civitati partim metu, partim patientia consuetudinem serviendi. 117. Cum illo ego te dominandi cupiditate conferre possum, ceteris vero rebus nullo modo comparandus es. Sed ex plurimis malis, quae ab illo rei publicae sunt inusta, hoc tamen boni extitit, quod didicit iam populus Romanus, quantum cuique crederet, quibus se committeret, a quibus caveret. Haec non cogitas, neque intellegis satis esse viris fortibus didicisse, quam sit re pulchrum, beneficio gratum, fama gloriosum tyrannum occidere? An, cum illum homines non tulerint, te ferent? 118. Certatim posthac, mibi crede, ad hoc opus curretur neque occasionis tarditas expectabitur).

49 Phil. XI 14, 37 "Portanto, bons são os que devemos recompensar; tácitos, os que devemos reconhecer; maus, aqueles cuja violência enfrentamos com a guerra e com armas legítimas" (Ergo aut boni sunt, quos etiam ornare, aut quieti, quos conservare debemus, aut impii, quorum contra furorem bellum et iusta arma cepimus).

50 Phil. XIII 6, 13 Atque etiam hoc M. Lepido providendum est, ne quid arrogantius quam eius mores ferunt facere videatur. 14. Si enim nos exercitu terret, non meminit illum exercitum senatus populique Romani atque universae rei publicae esse, non suum. At uti potest pro suo. Quid tum? Omniane bonis viris quae facere possunt facienda sunt? Etiamne si turpia, si perniciosa erunt, si facere omnino non licebit? Quid autem turpius aut foedius aut quod minus deceat quam contra senatum, contra cives, contra patriam exercitum ducere? Quid vero magis vituperandum quam id facere quod non liceat? Licet autem nemini contra patriam ducere exercitum, si quidem licere id dicimus quod legibus, quod more 
Por fim, para convencer os demais senadores a reconhecerem formalmente a liderança de Otaviano contra Marco Antônio, Cícero recorre à contradição de o senado empregar esforços para resguardar a república de uma nova contenda civil e promover o diálogo com Marco Antônio prescindindo, porém, da designação jurídica de seu antagonista:

"Dado o teor da carta dos cônsules Caio Pansa e Aulo Hírcio e do pró-pretor Caio César, assentamos louvores aos deuses imortais. Quem preceituou as ações de graças, reconheceu inadvertidamente nossos inimigos: jamais decretamos ações de graças em conflagrações civis. Decretamos, diria eu? Isso não foi sequer solicitado na carta dos vencedores. 23. O cônsul Sula geriu uma guerra civil; voltadas contra a cidade as suas tropas, expulsou e mandou matar quem lhe aprouve: $\mathrm{e}$ não houve menção alguma a ações de graças. Em seguida, veio a grave conflagração de Otávio: e, para o vencedor, não houve ação de graças. Sula, em comandante, desafrontou a vitória de Cina: e nenhuma ação de graças foi autorizada pelo senado. A V. Exa. mesmo, Públio Servílio, por acaso mandou-lhe missiva o seu colega [i.e., Júlio César] sobre a terribilíssima Farsália, querendo fosse alguma ação de graças autorizada? Decerto que não. Pediu-a sim, depois, por Alexandria e por Farnace; mas da Batalha de Farsália nem sequer solicitou o triunfo [ao senado]. Tal combate aniquilou cidadãos com os quais - estivessem eles não apenas vivos, como fossem igualmente vencedores - poderia a comunidade florescer e prosperar. 24. O mesmo sucedera nas demais conflagrações civis. Contudo, em meu consulado foi decretada - de forma nova e inaudita - a ação de graças não pelo arrasamento de inimigos, mas, sem que se tomassem as armas, pela proteção aos concidadãos. Por tal motivo, ou devem V. Exas., quando o pedem nossos comandantes em razão de suas façanhas importantíssimas em defesa da república, denegar-lhes as ações de graças - coisa que sucedeu a $[A u l o]$ Gabínio e a mais ninguém -, ou é necessário, ao decretar ações de graças, julguem V. Exas. inimigos aqueles contra cujos procedimentos V. Exas. as concedam" ${ }^{51}$.

maiorum institutisque conceditur. Neque enim, quod quisque potest, id ei licet, nec, si non obstatur, propterea etiam permittitur. Tibi enim exercitum, Lepide, tam quam maioribus tuis patria pro se dedit. Hoc tu arcebis hostem, fines imperi propagabis: senatui populoque Romano parebis, si quam ad aliam rem te forte traduxerit.

51 Phil. XIV 8, 22 Ex litteris enim C. Pansae A. Hirti consulum, C. Caesaris pro praetore, de bonore dis immortalibus habendo sententias dicimus. Supplicationem modo qui decrevit, idem imprudens hostes iudicavit; numquam enim in civili bello supplicatio decreta est. Decretam dico; ne victoris quidem litteris postulata est. 23. Civile bellum consul Sulla gessit, legionibus in urbem adductis quos voluit expulit, quos potuit occidit: supplicationis mentio nulla. Grave bellum Octavianum insecutum est: supplicatio nulla victori. Cinnae victoriam imperator ultus est Sulla: nulla supplicatio decreta a senatu. Ad te ipsum, $P$. Servili, num misit ullas collega litteras de illa calamitosissima pugna Pharsalia? Num te de supplicatione voluit referre? Profecto noluit. At misit postea de Alexandria, de Pharnace: Pharsaliae vero pugnae ne triumphum quidem egit. Eos enim cives pugna illa sustulerat, quibus non modo vivis, sed etiam victoribus incolumis et florens civitas esse posset. 24. Quod idem contigerat superioribus bellis civilibus. 
Redefinir a relação que o senado deve ter com Marco Antônio e justificar a violência como a única alternativa viável de reequilíbrio da forma de república: eis o marco em que deve se acomodar aquilo que, no contexto da crise de 44 a. C., Cícero reiteradamente julga procedente com a manutenção do genus mixtum e com as imposições da vida em comunidade. Cabe nele tãosomente o homem público cuja postura não provoque a colisão dos valores do grupo com as limitações das prerrogativas de cada uma das partes que formam o corpo civil. Isso explica, por exemplo, o porquê de Cícero preconizar as primeiras resoluções de Marco Antônio logo depois do assassinato de Júlio César (extinguir a função de ditador, suspender concessões fiscais e punir severamente os agitadores que se aproveitavam da confusão do momento) ${ }^{52}$ e propugnar a manutenção dos Atos de César, voltando-se, contudo, contra o mesmo Marco Antônio quando, ao passo que aguardava a chegada das tropas macedônicas, esse partiu para assumir a administração da Gália Cisalpina.

Com efeito, as definições de princeps e de res publica elaboradas por Cícero - e que subjazem aos argumentos presentes nas Filípicas para debelar a crise de 44 a. C. - partem do frágil princípio de que o cidadão conte com um rol de qualidades que o exortam a estar sempre disposto a colaborar com o grupo. Entende-se, aqui, que tais predicados respondam ao imperativo da obediência às determinações do senado, compreendido como o estamento central do genus mixtum tanto por sua autoridade como ainda por congregar os líderes da república. A necessidade da proteção ou da recuperação da república romana, ao mesmo tempo que simplifica a noção de tirania, admite inclusive a violência bélica como meio legítimo de repressão da ação do rebelde, o que contradiz os fundamentos mesmos da convivência entre os cidadãos: "é necessário, em tão grande alvoroço e conturbação, obedecer antes aos tempos, que aos costumes" ${ }^{\prime 53}$ é o que Cícero assevera quando propõe ao senado que Décimo e Marco Bruto assumissem função militar no confronto contra Marco Antônio. Dada essa contradição tão importante, não é de se admirar que o termo res publica continuasse, ainda que muito tempo depois da crise de 44 a. C., designando a forma romana de organização civil, e que o termo princeps entrasse no vocabulário político romano por uma porta distinta daquela que Cícero deixou aberta; foi necessário, contudo, esperar até

\footnotetext{
Nam mibi consuli supplicatio nullis armis sumptis non ob caedem hostium, sed ob conservationem civium novo et inaudito genere decreta est. Quam ob rem aut supplicatio re publica pulcherrime gesta postulantibus nostris imperatoribus deneganda est, quod praeter A. Gabinium contigit nemini, aut supplicatione decernenda hostes eos de quibus decernitis iudicetis necesse est.
}

52 Pbil. I 2, 4.

53 Phil. XI 11, 27 Necesse est enim in tanta conversione et perturbatione omnium rerum temporibus potius parere quam moribus. 
que Lucano ${ }^{54}$, Suetônio ${ }^{55}$ e Tácito $^{56}$ chamassem a atenção para o fato de que os acontecimentos situados no período entre a Guerra Civil de Júlio César contra Cneu Pompeu e a ascensão de Augusto haviam alterado sensivelmente a compreensão das concepçóes ciceronianas de princeps e de res publica.

\begin{abstract}
In this article, I intended to deduce some basic elements of the process that I temporarily call "transition" from the Roman Republic to Principate by analysing the Ciceronian vocabulary in the Philippics that characterizes Mark Anthony and refers to the crisis derived from Julius Caesar's murder. First, this vocabulary denounces the lack of dialogue between the opponents - what would serve as a basis for the argument of the urgency of civil war -; secondly, it assumes that specific conditions of social relations in the community failed. Therefore, when Cicero spoke up for the murder of the tyrant and advocated the military conflict as a reasonable reaction to Mark Anthony's rebellious behaviour, his arguments, although destined to crush dissent among Roman aristocrats and overcome the civil wars, contributed to understand the concentration of power in the hands of one statesman.
\end{abstract}

Keywords: Cicero; Philippics; Julius Caesar; Civil War; Ancient Rhetoric

\title{
ReFerênCIAS Bibliográficas
}

ABREU, Bruna Fernanda. A construção do éthos de Cícero e de Marco Antônio na Primeira Filípica. Monografia de conclusão de curso. Instituto de Estudos da Linguagem da Universidade Estadual de Campinas, 2014.

ARAÚJO, Cícero Romão Resende de. A forma da república: da constituição mista ao Estado. SP: Editora WMF Martins Fontes, 2013.

ARISTOTLE. Politics. Translated by H. Rackham. Cambridge/Harvard University Press; London:William Heinemann Ltd. 1944.

CICERO, Marcus Tullius. De re publica (selections): edited by James E. G. Zetzel. UK and New York: Cambridge Greek and Latin Classics University Press, 1995.

54 Luc. IV 820-824 "Mesmo que o poderoso Sula, o feroz Mário, o cruento Cina e a longa descendência de Júlio César adquirissem, com a espada, o direito de ceifar nossas vidas, a quem tamanho poder foi concedido?" (Ius licet in iugulos nostros sibi fecerit ense/ Sulla potens, Mariusque ferox, et Cinna cruentus,/ Caesareaeque domus series: cui tanta potestas/ Concessa est?).

55 Iul.77“A república [romana] não é nada; no máximo, uma expressão sem forma e sem conteúdo" (nibil esse rem publicam, appellationem modo sine corpore ac specie).

56 Tac. Ann. I 1 "O poder de Pompeu e de Crasso rapidamente passou para Júlio César; as armas de Lépido e de Antônio baixaram sob Augusto que, depois que tudo tivesse cedido às discórdias civis, aceitou o comando supremo sob a designação de príncipe" (Pompei Crassique potentia cito in Caesarem, Lepidi atque Antonii arma in Augustum cessere, qui cuncta discordiis civilibus fessa nomine principis sub imperium accepit). 
. Orations, Philippics 7- 14. Translated by D. R. Shackleton Bailey. Cambridge/Harvard University Press; London,:William Heinemann Ltd., 2009.

. Orations. Philippics 1-6. Translated by D. R. Shackleton Bailey.

Cambridge/Harvard University Press; London: William Heinemann Ltd., 2009.

. Pro Archia Poeta. Post reditum in senatum. Post reditum ad

Quirites. De domo sua. De haruspicum responsis. Pro Plancio; with an english translation by N. H. Watts. London and New York: Routledge, 1979.

. Pro Sestio. In Vatinium; with an english translation by R. Gardiner.

London and New York: Routledge, 1984.

GRIMAL, Pierre."Les éléments philosophiques dans l'idée de monarchie à Rome à la fin de la république”. In FLASHAR, Hellmut \& GIGON, Olof (org.) Aspects de la philosophie hellénistique - neuf exposés suivis de discussions. Genèvre: Fondation Hardt, 1985, tome XXXII.

LEPORE, Ettore. Il princeps ciceroniano e gli ideali politici della tarda republica. Napoli: Istituto italiano per gli studi storici, 1954.

LUCAIN. La Guerre Civile (La Pharsale). Texte établi et traduit par A. Bourgery. Paris: Les Belles Lettres, 1947, 2 vols.

PLATÃO. República. Tradução de Carlos Alberto Nunes. PA: Editora Universitária UFPA, $3^{\text {a }}$.ed., 2000.

POLIBIOS. Histoires - livre VI; texte établi et traduit par Raymond Weil. Paris: “Les Belles Lettres", 1977.

. História. Trad. Mário da Gama Kury. DF: Editora da UnB, $2^{a}$ ed., 1996.

SANTOS, Gilson C. dos. Entre os olhos e os ouvidosł a Guerra Civil entre César e Pompeu nas narrativas de Floro e Lucano. Dissertação de Mestrado. Faculdade de Filosofia, Letras e Ciências Humanas da Universidade de São Paulo, 2007.

SCATOLIN, Adriano. "A imagem de Otaviano nas Filípicas de Cícero". In: POMPEU, Ana Maria César; SOUSA, Francisco Edi de Oliveira (org.). Grécia e Roma no universo de Augusto. $1^{\mathrm{a}}$, ed. Coimbra/ São Paulo: Imprensa da Universidade de Coimbra/ Annablume, 2015, p. 51-69.

SUETONIUS. The Lives of the Twelve Caesars; an English Translation. Philadelphia: Gebbie \& Co., 1889.

TACITUS. Complete Works of Tacitus. New York: Random House, 1942.

Velleius Paterculus; Res Gestae Divi Augusti, edited and translated by F. W. Shipley. Cambridge/Harvard University Press; London, William Heinemann Ltd., 1951. 